\title{
PELATIHAN DAN PENDAMPINGAN PENYUSUNAN BORANG AKREDITASI SD YPK SOTA
}

\author{
Fredy $^{1 *}$ Mohamad Ilham², Ratna Purwanty ${ }^{3}$, Dewi Puji Rahayu ${ }^{4}$ \\ 1,2,3,4Universitas Musamus, Merauke, Indonesia \\ *Penulis Koresponsensi, email: fredy_pgsd@unmus.ac.id
}

Article History
Received:21/01/2021
Revised:01/02/2021
Accepted:01/02/2021

\begin{abstract}
SD YPK Sota, located in the village of Sota, on the RI-PNG border, has long ended its accreditation period. The last accreditation was in 2012 with a C rating. In fact, the eight components of the national education standard have been implemented by partner schools but the documents and activity reports are not well-administered. The results of interviews with partner school principals obtained the same problem, namely the low value of each SNP component referring to the accreditation instrument. Training programs and assistance for the preparation of accreditation forms by the community service team are the solutions offered to help partner school problems. The stages of this community service program include: 1) the training stage, 2) the assistance stage for the preparation of accreditation forms, 3) the assistance stage for the fulfillment of accreditation physical documents, 4) the evaluation stage. The training in the form of providing material on the role of accreditation for the fulfillment of SNP, accreditation tools and accreditation assessment instruments was able to provide understanding to the form drafting team about the importance of school accreditation as a form of school / madrasah accountability to the public and an understanding of the procedures for drafting forms referring to Permendikbud No. 2. In 2017, the focus of the form preparation team is to fulfill every element of the assessment in the assessment instrument. Training in the fulfillment of physical documents and supporting documents provides understanding and skills to the form drafting team in preparing physical documents and supporting documents in accordance with the technical instructions and fulfillment lists that have been made previously. Training through tutorials on how to fill in accreditation forms online provides understanding and skills to the form drafting team on how to use the Sispena-S/M application (School/Madrasah Accreditation Assessment System).
\end{abstract}

Keywords: training, mentoring, accreditation

Abstrak. SD YPK Sota yang terletak di desa Sota perbatasan RI-PNG telah lama berakhir masa akreditasinya. Akreditasi terakhir pada tahun 2012 dengan peringkat C. Sebenarnya kedelapan komponen standar nasional pendidikan telah dilaksanakan oleh sekolah mitra namun dokumen dan laporan kegiatan kurang teradministrasi dengan baik. Hasil wawancara dengan kepala sekolah mitra diperoleh masalah yang sama yaitu rendahnya nilai setiap komponen SNP yang mengacu pada instrumen akreditasi. Program pelatihan dan pendampingan penyusunan borang akreditasi oleh tim pengabdian masyarakat menjadi solusi yang ditawarkan untuk membantu permasalahan sekolah mitra. Tahapan program pengabdian masyarakat ini meliputi: 1) tahap pelatihan, 2) tahap pendampingan penyusunan borang akreditasi, 3) tahap pendampingan pemenuhan dokumen fisik akreditasi, 4) tahap evaluasi. Pelatihan berupa pemberian materi peran akreditasi terhadap pemenuhan SNP, perangkat akreditasi dan instrumen penilaian akreditasi mampu memberikan pemahaman pada tim penyusun borang tentang pentingnya akreditasi sekolah sebagai bentuk pertanggungjawaban sekolah/madrasah kepada publik dan pemahaman tentang tatacara penyusunan borang yang mengacu pada Permendikbud No. 2. Tahun 2017 sehingga fokus tim penyusun borang adalah memenuhi setiap unsur penilaian dalam instrumen penilaian. Pelatihan dalam pemenuhan dokumen fisik dan dokumen pendukung memberi pemahaman dan keterampilan kepada tim penyusun borang dalam menyiapkan dokumen fisik dan dokumen pendukung sesuai dengan petunjuk teknis dan list pemenuhan kebutuhan yang telah dibuat sebelumnya. Pelatihan melalui tutorial tata cara pengisian borang akreditasi secara online memberi pemahaman dan keterampilan kepada tim penyusun borang tentang tata cara menggunakan aplikasi Sispena-S/M (Sistem Penilaian Akreditasi Sekolah/Madrasah).

Kata Kunci: pelatihan, pendampingan, akreditasi

How to Cite: Fredy, F., Ilham, M., Purwanty, R., \& Rahayu, D. P. (2021). PELATIHAN DAN PENDAMPINGAN PENYUSUNAN BORANG AKREDITASI SD YPK SOTA. Mitra Mahajana: Jurnal Pengabdian Masyarakat, 2(1), 7-14. https://doi.org/10.37478/mahajana.v2i1.802 


\section{PENDAHULUAN}

Kelayakan suatu program atau satuan pendidikan ditetapkan berdasarkan hasil penilaian Standar Nasional Pendidikan (SNP) dan aturan yang terkait lainnya, ditetapkan dalam bentuk nilai akreditasi. Akreditasi merupakan kegiatan penilaian berdasarkan fakta di lapangan (Awaludin, 2017). Akreditasi dilakukan oleh suatu badan akreditasi yang ditunjuk oleh pemerintah untuk menilai suatu program atau satuan pendidikan secara komprehensif, obyektif dan transparan sesuai dengan instrumen atau indikator yang telah ditetapkan (Zulkifli, 2015). Melalui akreditasi sekolah diperoleh gambaran sesungguhnya tentang kinerja sekolah dan kualitas sekolah (Subiyanto \& Wiratno, 2012). Akreditasi menjadi alat refeleksi diri bagi sekolah untuk memperbaiki kekurangannya dan meningkatkan keunggulannya. Badan Akreditasi Nasional Sekolah/Madrasah (BAN-S/M) sebagai badan yang melakukan akreditasi telah menetapkan sekolah yang akan diakreditasi tahun 2019 yaitu semua sekolah yang belum terakreditasi, telah berakhir masa berlakunya atau masa berlakunya telah berakhir (kadaluarsa) minimal satu tahun dengan prioritas sekolah yang masa telah lama kadaluarsa masa berlakunya (Toharudin, 2019).

SD YPK Sota merupakan mitra dari kegiatan pengabdian masyarakat yang terletak di jalan Trans Irian (jalan poros perbatasan Indonesia-PNG) Desa Sota Kabupaten Merauke. Sekolah tersebut menjadi prioritas untuk diakreditasi tahun 2021 karena masa berlakunya telah lama berakhir. Akreditasi terakhir SD YPK Sota pada tahun 2012 dengan peringkat C. Berdasarkan hasil observasi awal dapat diketahui bahwa SD YPK Sota memiliki 15 guru dan 225 peserta didik yang tersebar dalam 10 rombongan belajar. Sekolah telah memiliki fasilitas yang cukup memadai. Rendahnya hasil penilaian komponen SNP sangat dipengaruhi oleh faktor manajerial kepala sekolah, guru dan tenaga pendidik lainnya (Wahyuni, 2018). Faktor lainnya adalah kurangnya persiapan sekolah khususnya dalam penyiapan dokumen fisik, terbatasnya waktu dalam melakukan evaluasi diri serta koordinasi yang tidak maksimal antara tim borang sekolah (Sholihin et al., 2018). Hasil wawancara dengan kepala sekolah menyebutkan bahwa sebenarnya kedelapan komponen standar nasional pendidikan telah dilaksanakan oleh sekolah namun dokumen dan laporan kegiatan kurang teradministrasi dengan baik. Mereka juga kesulitan dalam menyusun borang akreditasi dan mempersiapkan dokumen fisik akreditasi. Hal ini karena kurangnya pengetahuan mereka tentang penyusunan borang akreditasi dan kelengkapan bukti fisik dan bukti penunjang yang sesuai dengan instumen akreditasi. Inilah yang menjadi salah satu faktor tidak optimalnya hasil yang mereka peroleh. Memang terdapat perbedaan instrumen pada saat akreditasi tahun 2012 dan saat reakreditasi tahun 2020, namun bukan instrumen yang menjadi permasalahannya tetapi pada pihak sekolah bagaimana melakukan evaluasi kinerjanya setiap waktu (Rahman et al., 2017).

Sekolah perlu mencermati komponen-komponen yang belum maksimal nilainya dan melakukan evaluasi terhadap kelemahan komponen tersebut, kemudian membuat program perbaikan yang termuat RKAS selanjutnya. Semua komponen yang mengacu pada SNP masih memiliki kelemahan. Semua komponen inilah yang harus menjadi fokus perbaikan oleh sekolah. Perlu adanya strategi untuk mengoptimalkan komponen-komponen penilaian sehingga dapat menaikan status akreditasi. SD YPK Sota menargetkan tahun 2021 dapat terakreditasi B. Target tersebut dapat tercapai jika sekurang-kurangnya memperoleh nilai akhir 81. Untuk itu, perlu adanya pelatihan dan pendampingan penyusunan borang akreditasi agar menambah pengetahuan tentang penyusunan borang akreditasi sekolah dan kelengkapan dokumen fisik akreditasi sehingga nantinya dapat meningkatkan status akreditasi SD YPK Sota.

\section{METODE PELAKSANAAN}

Metode yang ditempuh untuk melaksanakan solusi permasalahan sekolah mitra adalah pelatihan dan pendampingan penyusunan borang akreditasi dengan tahapan meliputi: 1) tahap pendahuluan, 2) tahap pelaksanaan, 3) tahap evaluasi.

1. Tahap pendahuluan: Pada tahapan ini dilakukan dengan cara observasi awal, wawancara mendalam dan studi dokumentasi terkait hasil penilaian akreditasi sebelumnya. Selanjutnya 
dilakukan FGD (forum group discussion) untuk mendalami permasalahan sekolah mitra dan menentukan solusi penyelesaiannya. Selanjutnya sekolah mitra dan tim pengabdian masyarakat menyepakati prioritas permasalahan yang diselesaikan melalui kegiatan pengabdian masyarakat. Tahap pendahuluan ini akan dilaksanakan selama satu dua minggu

2. Tahap pelaksanaan: Pada tahapan ini dilakukan dengan cara pelatihan, pendampingan, penilaian terbimbing.

- pelatihan dengan materi: peran akreditasi terhadap pemenuhan SNP, 2) perangkat akreditasi, 3) instrumen penilaian akreditasi, 4) pedoman penyusunan dokumen fisik akreditasi, 5) tata cara pengisian borang akreditasi secara online. Dilaksanakan selama dua minggu

- Pendampingan 1: menyusun borang akreditasi sekolah. Selama proses penyusunan borang akreditasi, tim pengabdian masyarakat terus mendampingi kegiatan tim borang sekolah. Pendampingan lebih difokuskan pada komponen SNP yang mengacu pada instrumen akreditasi SD/MI sebanyak 119 item pernyataan meliputi delapan komponen standar. Komponen isi sebanyak 10 item, komponen proses sebanyak 21 item, komponen kompetensi sebanyak 7 item, komponen PTK sebayak 16 item, komponen sarana dan prasarana sebanyak 21 item, komponen pengelolaan sebanyak 15 item, komponen pembiayaan sebanyak 16 item dan komponen penilaian sebanyak 13 item (BAN-S/M, 2017). Dilaksanakan selama dua bulan.

- Pendampingan 2: menyiapkan dokumen fisik penunjang akreditasi. Pendampingan oleh tim pengabdian masyarakat difokuskan pada diksusi, tanya jawab, berbagi pengetahuan dan pengalaman kaitannya dengan bukti fisik akreditasi. Dilaksanakan selama dua bulan.

- Penilaian terbimbing: melaksanakan simulasi penilaian akreditasi yang disesuaikan dengan penilaian yang dilakukan oleh BAN-S/M menggunakan istrumen akreditasi. Apabila hasil penilaian masih dibawah standar yang ditargetkan yaitu 81, maka tim borang akreditasi mitra dengan pendampingan tim pengabdian masyarakat melakukan perbaikan pada komponen yang masih dibawah standar tersebut. Dilaksanakan selama satu bulan.

3. Tahap evaluasi: pada tahapan ini tim pengabdian masyarakat melakukan evaluasi secara menyeluruh terhadap pelaksanaan program pengabdian masyarakat. (Marjuki et al., 2018) menyebutkan evaluasi bertujuan membandingkan data yang ada dengan data yang sesuai kriteria, sehingga dalam kegiatan pengabdian ini evaluasi dilakukan untuk membandingkan hasil yang diperoleh melalui program pengabdian dan dibandingkan dengan dengan target luaran yang ditetapkan. Dilaksanakan selama satu bulan.

\section{HASIL DAN PEMBAHASAN}

Pelaksanaan kegiatan pengabdian dilaksanakan diawali dengan studi awal dan penyusunan instrument penilaian. Pelaksanaan pengabdian ini diawali dengan observasi di SD YPK Sota. Hasil wawancara dengan kepala sekolah menunjukkan bahwa sekolah membutuhkan pelatihan dalam penyusunan borang akreditasi sesuai kriteria penilaian. Sebenarnya kedelapan komponen standar nasional pendidikan telah dilaksanakan oleh sekolah namun dokumen dan laporan kegiatan kurang teradministrasi dengan baik. Hal ini karena kurangnya pengetahuan mereka tentang penyusunan borang akreditasi dan kelengkapan bukti fisik dan bukti penunjang yang sesuai dengan instumen akreditasi (Fredy et al., 2019). Rendahnya hasil penilaian komponen SNP sangat dipengaruhi oleh manajerial kepala sekolah, guru dan tenaga pendidik lainnya (Wahyuni, 2018). Sekolah tersebut menjadi prioritas untuk diakreditasi tahun 2021 karena masa berlakunya telah lama berakhir. Akreditasi terakhir SD YPK Sota pada tahun 2012 dengan peringkat C. SD YPK Sota memiliki 15 guru dan 225 peserta didik yang tersebar dalam 10 rombongan belajar. Sekolah telah memiliki fasilitas yang cukup memadai.

Memang terdapat perbedaan instrumen pada saat akreditasi tahun 2012 dan saat reakreditasi tahun 2019, namun bukan instrumen yang menjadi permasalahannya tetapi pada pihak sekolah bagaimana melakukan evaluasi kinerjanya setiap waktu (Rahman et al., 2017). 
Sekolah perlu mencermati komponen-komponen yang belum maksimal nilainya dan melakukan evaluasi terhadap kelemahan komponen tersebut, kemudian membuat program perbaikan yang termuat RKAS selanjutnya. Kelemahan yang menjadi fokus perbaikan SD YPK Sota disajikan dalam tabel 1 berikut.

Tabel 1. Hasil penilaian pada standar nasional pendidikan di SD YPK Sota

\begin{tabular}{clc}
\hline No & Komponen penilaian & Hasil penilaian \\
\hline 1 & Isi & 68 \\
2 & Proses & 77 \\
3 & Kompetensi Lulusan & 41 \\
4 & PTK & 47 \\
5 & Sarana dan prasarana & 51 \\
6 & Pengelolaan & 51 \\
7 & Pembiayaan & 51 \\
8 & Penilaian & 69 \\
Nilai & $\mathbf{5 7}$ \\
Peringkat & $\mathbf{C}$ \\
\hline
\end{tabular}

Tabel 1 di atas menunjukkan bahwa belum adanya komponen yang memenuhi nilai minimal B yang mengacu pada SNP. Setiap komponen ini harus menjadi fokus perbaikan oleh sekolah. Untuk itu perlu adanya strategi untuk mengoptimalkan komponen-komponen penilaian sehingga dapat menaikan status akreditasi. SD YPK Sota menargetkan tahun 2021 dapat terakreditasi B. Target tersebut dapat tercapai jika sekurang-kurangnya memperoleh nilai akhir 81. Berdasarkan hal tersebut di atas tim pengabdian dan sekolah sepakat untuk mengadakan pelatihan dan pendampingan penyusunan borang akreditasi agar menambah pengetahuan sekolah tentang penyusunan borang akreditasi dan kelengkapan dokumen fisik akreditasi sehingga apa yang ditarget oleh SD YPK Sota dapat tercapai dengan baik.

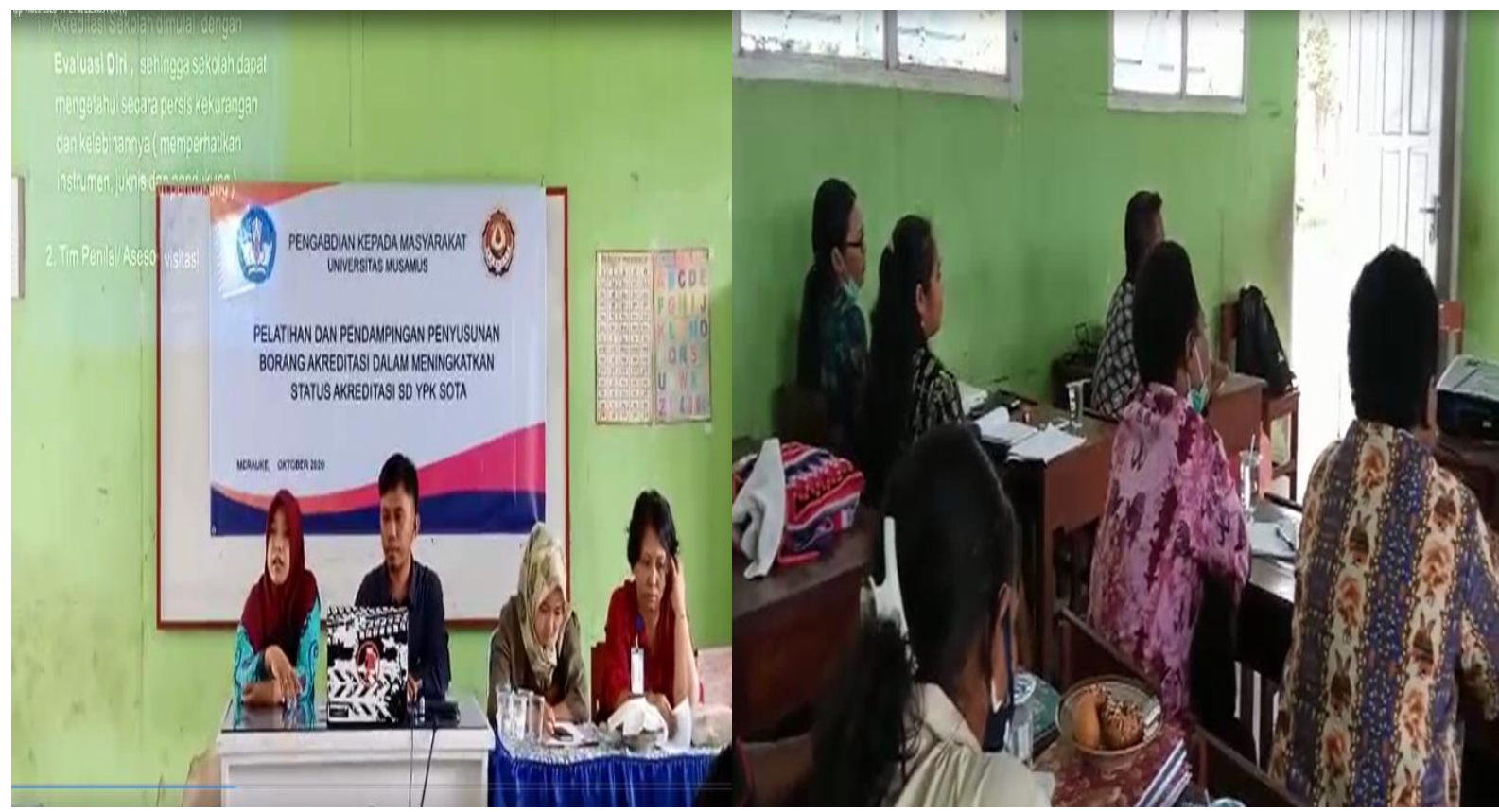

Gambar 1. Penjelasan materi pelatihan borang akreditasi 
Pemaparan materi peran akreditasi terhadap pemenuhan SNP berupa dasar hukum, fungsi, tujuan dan manfaat akreditasi dapat menumbuhkembangkan kesadaran akan pentingnya akreditasi sekolah sebagai wujud tanggung jawab sekolah kepada masyarakat mengenai pelayanan pendidikan yang diberikan telah memenuhi standar yang ditetapkan. Selain itu juga sebagai informasi kepada berbagai pihak tentang kelayakan sekolah berdasarkan indikator penilaian yang telah ditetapkan oleh pemerintah. Hasil penilaian akreditasi dapat menjadi dasar sekolah, pemerintah, dan masyarakat untuk merumuskan kebijakan dalam meningkatkan mutu dan kualitas layanan sekolah.

Pemaparan materi perangkat akreditasi dan instrumen penilaian akreditasi memberikan pemahaman kepada tim penyusun borang mengenai perangkat akreditasi yang termuat dalam Peraturan Menteri Pendidikan dan Kebudayaan No. 002 Tahun 2017 sehingga fokus tim penyusun borang adalah memenuhi setiap komponen dalam instrumen penilaian. Instrumen akreditasi SD/MI sebayak 119 item pernyataan. Komponen isi pada item pernyataan 1-10, komponen proses pada item pernyataan 11-31, komponen kompetensi lulusan pada item pernyataan 32-38, komponen PTK pada item pernyataan 39-54, komponen sarana dan prasarana pada item pernyataan 55-75, komponen pengelolaan pada item pernyataan 76-90, komponen pembiayaan pada item pernyataan 91-106 dan komponen penilaian pada item pernyataan 107-119.

Pemaparan pedoman penyusunan dokumen fisik dan dokumen pendukung memberi pemahaman kepada tim penyusun borang dalam menyiapkan dokumen fisik dan dokumen pendukung sesuai dengan petunjuk teknis dan list pemenuhan kebutuhan yang telah dibuat sebelumnya. Penyiapan dokumen fisik akreditasi diharapkan berimplikasi pada tertibnya pengarsipan administrasi dalam hal ini kesediaan dokumen-dokumen sekolah yang substansi (Karyanto et al., 2015). Berikut contoh alur penyusunan borang akreditasi pada standar isi.

\section{Standar Isi}

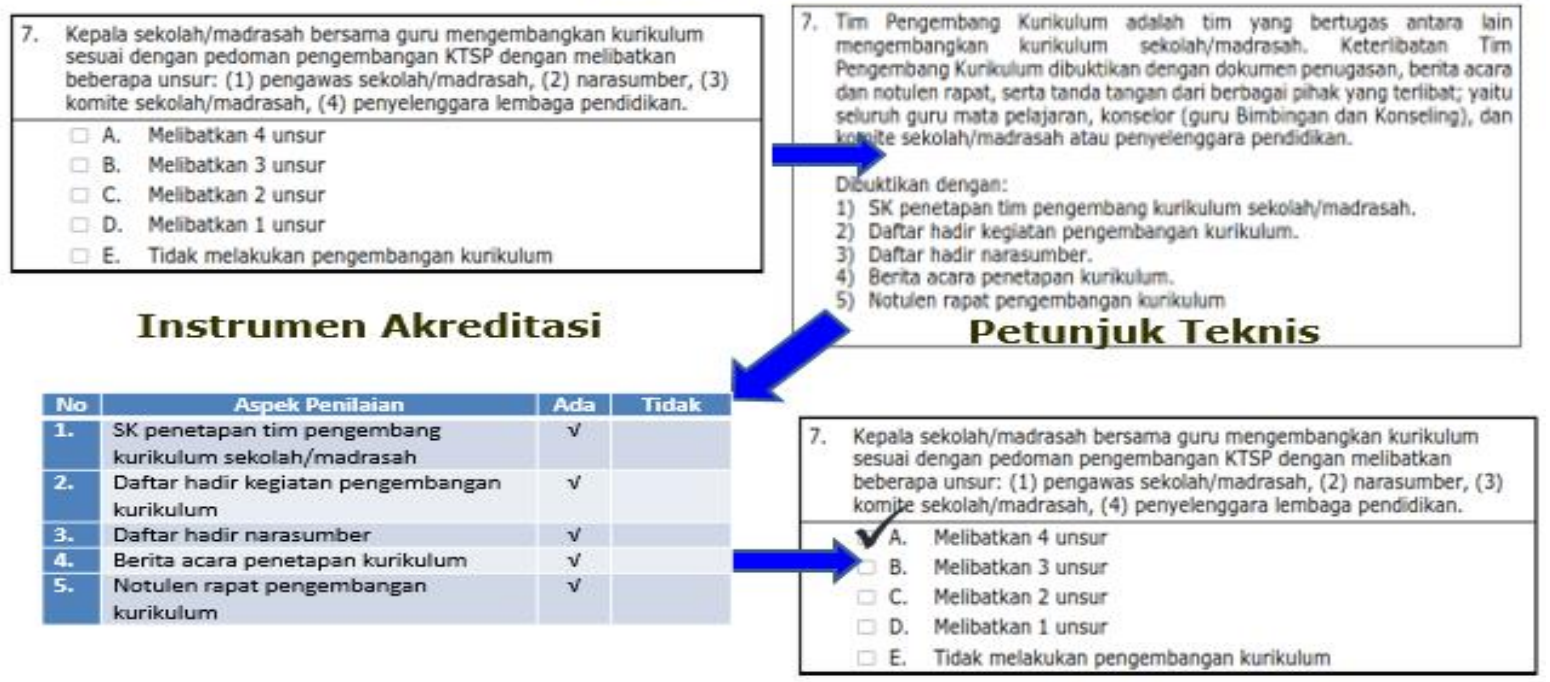

\section{Instrumen Pengumpulan Data dan Informasi Pendukung}

\section{Gambar 2. Contoh alur penyusunan borang akreditasi pada standar isi}

Pemaparan materi tentang tata cara pengisian borang akreditasi secara online memberi pemahaman kepada tim penyusun borang tentang tata cara pengisian pada aplikasi SispenaS/M (Sistem Penilaian Akreditasi Sekolah/Madrasah) tahun 2020. Dengan menggunakan metode tutorial yang diberikan tim penyusun memiliki pemahaman tentang cara mengirim borang akreditasi tahun 2020 melalui aplikasi Sispena yaitu aplikasi penilaian akreditasi yang berbasis web online, dimana bisa akses dimana saja, kapan saja dengan syarat terhubung 
dengan internet. Aplikasi ini dapat diakses menggunakan perangkat komputer, laptop, dan handphone (HP) atau perangkat lain dengan resolusi kecil. Berikut salah satu tampilan aplikasi Sispena S/M.

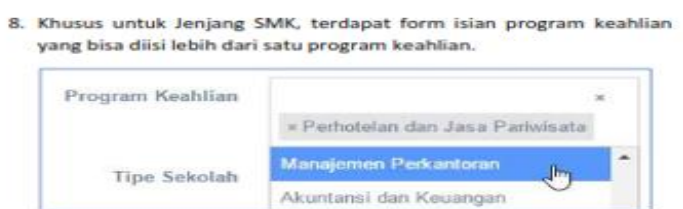

9. Selain itu, data yang wajib diisi sekolah adalah status akreditasi terakhir, tahun akreditasi serta visi dan misi.

$$
\text { 10. Setelah terisi selanjutnya klik Submit: }
$$

11. Selanjutnya sekolah mengklik Menu Data Isian Akreditasíatau DIA ang ada disamping kiri untuk memulai proses penginputan isia

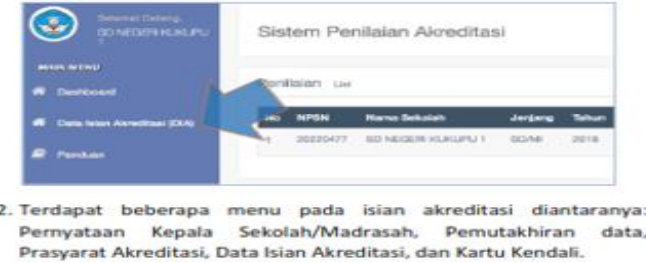
Pernyataan Kepala Sekolah/Madrasah. Pemutakhiran dat

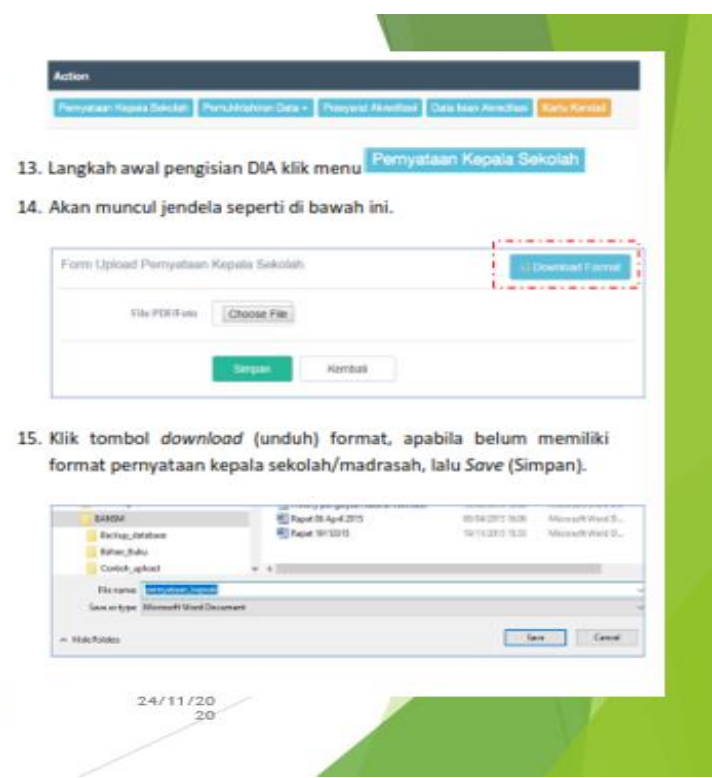

14. Akan muncul jendela seperti di bawah in.

Gambar 3. Tampilan aplikasi Sispena S/M

Analisis kesiapan borang akreditasi dan bukti fisik yang telah disusun oleh tim borang akreditasi sekolah mitra

Dokumen fisik disusun sesuai petunjuk teknis penilaian. Berdasarkan hasil simulasi penilaian maka diperoleh nilai rata-rata berdasarkan tingkat kesiapan dokumen fisik borang akreditasi.

Tabel 2. Tingkat Kesiapan Dokumen Fisik Borang Akreditasi

\begin{tabular}{|c|c|c|}
\hline No & $\begin{array}{c}\text { Komponen } \\
\text { penilaian }\end{array}$ & Persentase (\%) \\
\hline 1 & Isi & 90 \\
\hline 2 & Proses & 95 \\
\hline 3 & Kompetensi Lulusan & 95 \\
\hline 4 & PTK & 80 \\
\hline 5 & Sarana dan prasarana & 80 \\
\hline 6 & Pengelolaan & 80 \\
\hline 7 & Pembiayaan & 85 \\
\hline 8 & Penilaian & 85 \\
\hline $\begin{array}{l}\text { Rata-r } \\
\text { boran }\end{array}$ & $\begin{array}{l}\text { tingkat kesiapan dokumen fisik } \\
\text { reditasi }\end{array}$ & 86,25 \\
\hline
\end{tabular}


Berdasarkan tabel 2 di atas menunjukkan hasil analisis kesiapan dokumen fisik borang akreditasi SD YPK Sota sebesar 86,25\% (sangat baik). Hasil analisis ini memberikan gambaran bahwa tim akreditasi SD YPK Sota memiliki kesiapan dan tanggung jawab dalam menyiapkan borang akreditasi sekolah yang direncanakan akan mengajukan reakreditasi pada awal tahun 2021. Kesiapan dokumen borang akreditasi ini merupakan komitmen SD YPK Sota dalam meningkatkan status akreditasi sekolah dengan target minimal B.

\section{SIMPULAN DAN TINDAK LANJUT}

Program pelatihan dan pendampingan penyusunan borang akreditasi oleh tim pengabdian masyarakat menjadi solusi yang ditawarkan untuk membantu permasalahan sekolah mitra. Tahapan program pengabdian masyarakat ini meliputi: 1) tahap pelatihan, 2) tahap pendampingan penyusunan borang akreditasi, 3) tahap pendampingan pemenuhan dokumen fisik akreditasi, 4) tahap evaluasi. Pelatihan berupa pemberian materi peran akreditasi terhadap pemenuhan SNP, perangkat akreditasi dan instrumen penilaian akreditasi mampu memberikan pemahaman pada tim penyusun borang tentang pentingnya akreditasi sekolah sebagai bentuk pertanggungjawaban sekolah/madrasah kepada publik dan pemahaman tentang tatacara penyusunan borang yang mengacu pada Permendikbud No. 2 . Tahun 2017 sehingga fokus tim penyusun borang adalah memenuhi setiap unsur penilaian dalam instrumen penilaian. Pelatihan dalam pemenuhan dokumen fisik dan dokumen pendukung memberi pemahaman dan keterampilan kepada tim penyusun borang dalam menyiapkan dokumen fisik dan dokumen pendukung sesuai dengan petunjuk teknis dan list pemenuhan kebutuhan yang telah dibuat sebelumnya. Pelatihan melalui tutorial tata cara pengisian borang akreditasi secara online memberi pemahaman dan keterampilan kepada tim penyusun borang dalam mengirim borang melalui aplikasi Sispena-S/M. Setelah kegiatan pengabdian selesai dilaksanakan, tim pengabdian akan terus memantau dan mendampingi sekolah mitra sampai pada pelaksanaan reakreditasi sekolah yang direncanakan pada tahun 2021.

\section{DAFTAR PUSTAKA}

Awaludin, A. A. R. (2017). Akredıtası Sekolah Sebagaı Suatu Upaya Penjamınan Mutu Pendıdıkan di Indonesia. Jurnal SAP, 2(1), 12-21. https://doi.org/10.1017/CB09781107415324.004

Fredy, Tembang, Y., \& Purwanty, R. (2019). Analisis Kepuasan Orangtua dan Siswa terhadap Kualitas Layanan Pendidikan Dasar. Musamus Journal of Primary Education, 2(1), 59-66. https://doi.org/10.35724/musjpe.v2i1.1874

Karyanto, U. G., Rahman, A., \& Darwin, D. (2015). Implikasi Akreditasi Sekolah Terhadap Peningkatan Mutu Tata Kelola Smk Negeri 1 Oku. Jurnal Manajemen Pendidikan Indonesia, $7(2), 43-57$.

Marjuki, Mardapi, D., \& Kartowagiran, B. (2018). Pengembangan Model Akredıtası Sekolah Menengah Atas/Madrasah Alıyah (SMA/MA). Jurnal Penelitian Dan Evaluasi Pendidikan, 22(1), 105-117.

Rahman, M. H., Saprudin, S., Mubarak, H., \& Hamid, F. (2017). Evaluasi Program IbM Pendampingan Penyusunan Borang Akreditasi bagi Sekolah Dasar di Kota Ternate. Titian Ilmu: Jurnal Ilmiah Multi Sciences, 9(2), 59-65. https://doi.org/10.30599/jti.v9i2.93

Sholihin, E. N. C., Bafadal, I., \& Sunandar, A. (2018). Pengelolaan Persiapan Akreditasi Sekolah. Jurnal Administrasi Dan Manajemen Pendidikan, 1(2), 171-178. https://doi.org/10.17977/um027v1i22018p171

Subiyanto, \& Wiratno, S. (2012). Analisis Kinerja Badan Akreditasi Nasional Sekolah /Madrasah. Jurnal Pendidikan Dan Kebudayaan, 18(3), 310-318. 
Toharudin, T. (2019). Kebijakan Pelaksanaan Akreditasi Sekolah / Madrasah Tahun 2019.

Wahyuni, S. (2018). Upaya Meningkatkan Nilai 8 Standar Nasional Pendidikan Akreditasi Sekolah melalui Supervisi Pembimbingan Terpadu pada Madrasah Ibtidaiyah di Kabupaten Sleman. Jurnal Pendidikan Madrasah, 3(1), 55-63.

Zulkifli. (2015). Kınerja Badan Akredıtası Provinsi Sekolah/Madrasah (BAP S/M) dalam Menıngkatkan Mutu Pendıdıkan di Provinsi Sulawesi Tenggara. Jurnal Al-Ta'dib, 8(2), 168190. 